\title{
Minority governments and budget deficits: the role of the opposition
}

\author{
Albert Falcó-Gimeno ${ }^{\text {a,c }}$ \\ Ignacio Jurado ${ }^{b, c, *}$ \\ ${ }^{a}$ Departament de Ciències Polítiques i Socials, Universitat Pompeu Fabra, Edifici Jaume I (Campus de \\ la Ciutadella) - C/ Ramon Trias Fargas, 25-27, 08005, Barcelona, Spain. \\ ${ }^{b}$ Nuffield College, University of Oxford, New Road, OX1 1NF, United Kingdom. \\ c Juan March Institute, C/ Castelló 77, 28006, Madrid, Spain.
}

Accepted Author Manuscript, published in 2011 in the European Journal of Political Economy 27(3): 554-565, available at:

http://www.sciencedirect.com/science/article/pii/S0176268011000280

\begin{abstract}
When governments are in a parliamentary minority they have to negotiate with opposition parties over the annual budget. We argue that, as a consequence, the preferences of the opposition concerning fiscal outcomes should be reflected in the yearly budget balances. We present a theoretical argument in which the opposition faces a trade-off. It has a short-term interest in deficits since they can signal a weak government, but a long-term aversion to them because, if they reach office, they will have to deal with the burden of increased debt. Empirically, we find that opposition parties affect deficit outcomes depending on their probability of governing in the next term and the weakness of the incumbent government. When the opposition is mainly concentrated in one party, it will perceive it is likely it will take over the government and this will make the opposition deficit averse in the current period. However, if the minority government is a coalition, then a concentrated opposition might see deficits as an opportunity to reach office earlier and might be willing to pass budgets with deficit.
\end{abstract}

Keywords:

Deficits

Minority governments

Opposition

Budget approval.

JEL classification:

D72

H11

H62

* Corresponding author: New Road, Nuffield College, University of Oxford. OX1 1NF, Oxford, United Kingdom. Tel.: +44 1865278663; Fax: +44 1865278621; E-mail: ignacio.jurado@politics.ox.ac.uk 


\section{Introduction}

It has been widely argued that the phenomenon of budget deficits cannot be fully explained by economic variables (Volkerink and de Haan, 2001). In parallel, other studies have documented a trend of systematic deficits in Western economies from 1973 until the mid-nineties. If public spending was mainly countercyclical, these deficits would have only been temporary tools (Barro, 1979; Alesina et al., 1992). Similarly, if governments were rational office seekers, they would predominantly employ them in pre-electoral years (Alesina et al., 1993). But none of these explanations can provide a complete and satisfactory account to the real-world evidence. The key question in this field is why governments have sometimes used them systematically by following an apparently incoherent pattern that finally led many countries to reach unsustainable levels of debt (Grilli et al., 1991; Bravo and Silvestre, 2002).

Finding common patterns in the production of budget deficits beyond a purely economic perspective has already provided fertile ground for political economists. Following several seminal works published around twenty years ago (Roubini and Sachs, 1989; Grilli et al., 1991; Edwards and Tabellini, 1991; Roubini, 1991), an expanding literature has explored and analysed various political explanations for fiscal deficits. This paper tries to take a step forward in this area by assessing the role of an actor that has seldom been taken into account hitherto: the opposition.

We provide evidence demonstrating that the type of opposition is key in explaining deficit outcomes when governments are in a parliamentary minority. Depending on the opposition's likelihood of being part of a future government and the weakness of the minority government, oppositions will support different deficit outcomes.

This article is organised as follows. In section two we claim that the influence of the opposition on minority governments' performance has still not been addressed in sufficient detail and explain how that can be improved. Our theoretical argument and hypotheses are presented in the third section. Section four deals with the data and other methodological considerations, while section five provides our empirical results and discusses them. Finally, the last section suggests directions for further research and concludes. 


\section{Minority governments, oppositions, and fiscal performance: a cocktail to be further explored}

According to Strøm (1985, 1990), conventional wisdom has viewed minority governments as being more inclined towards political malaise, irrationality, and poor performance. This view may be understandable if we look back to historical events that could give rise to negative perceptions of minority governments. The interwar period, with the Weimar or the Fourth French Republics, is a clear example. However, it is obvious that these events do not represent today's realities.

Non-historical studies have also focused on minority cabinets' performance. As D’Alimonte (1978) stresses, these assessments have been based on two traditional criteria: stability and legislative effectiveness. Minority governments have seldom been positively evaluated on either account. Some authors have empirically shown that these type of governments are commonly less durable (Lijphart, 1984; Warwick, 1979) since they may rapidly give way either to minimum winning coalitions via expansion or to early parliamentary dissolution (Dodd, 1976). This tendency has also been observed by Taylor and Herman (1971), although they found much less dramatic differences. Nonetheless research concerning these governments' performance in office "is generally restricted to impressionistic evaluations with a largely negative flavour" and "[p]artly this is because there are few adequate measures of government performance" (Strøm, 1990: 17).

One of these measures of performance may be fiscal deficits. The extent to which the formal composition of governments or, more generally, the fragmentation of power influence the likelihood and magnitude of budget deficits has inspired a considerable amount of research during the previous two decades (e.g. Roubini and Sachs, 1988, 1989; Alesina et al., 1992; de Haan and Sturm, 1994; Borge, 2005). The motivation underlying these studies has been to address the issue of disagreement between parties within office. However, in that process they have overlooked the possible need for agreement with actors beyond government. This approach owes much to the contribution of Roubini and Sachs (1989), who developed a political dispersion index of 
15 OECD countries, covering the period from the mid-sixties to the mid-eighties. Using this index, they identified an average gap of a 1\% deficit over GDP between single party majority governments and minority ones (see also Alesina et al., 1992 and de Haan and Sturm, 1994). However, the use of this index as a single variable assumed ex ante a specific ranking in promoting deficits, where coalitions are more prone than single party governments, and minorities are more prone than coalitions. Consequently, some have judged these findings to be inconsistent and lacking proper robustness (de Haan and Sturm, 1997).

Edin and Ohlsson (1991) moved a step forward by fragmenting the index and using each category as a single dummy in their regressions. This procedure allowed them to show that only parliamentary minorities are more likely to fall into budget deficits. Their results imply that either belonging to a majority government encourages politicians to be responsible or that minority governments are too weak and thus unable to adjust the budget. However nothing of this is mentioned in their work and therefore these intriguing results lack a proper theoretical explanation.

Nonetheless other authors have simultaneously cast doubts on the previous findings and also refuted the view that more unified governments are less prone to deficits (Alt and Lowry, 1994) or that divided governments systematically fall into deficits (de Haan and Sturm, 1997). Complementing the traditional view of coalitions as big spenders (e.g. Jones et al., 1997), Perotti and Kontopoulos (2002) showed that these type of governments might need to satisfy their respective (more numerous) constituencies, but not always through deficits and irresponsible fiscal behaviour. Finally, other scholars have focused more on the rules and the process of passing a budget, rather than on the number of parties in government (Hallerberg and Von Hagen, 1999).

In sum, this deficit-focused literature provides inconclusive evidence about the influence of specific types of governments on deficit outcomes. This probably has to do with the fact that the 'type of government' may not be a variable that produces particular outcomes per se, but rather its influence may depend on the interaction with other factors. We argue that a conditional effect is missing, namely that provided by the interests of the opposition. This is why we introduce this actor here as a crucial determinant of deficit outcomes. 
Strikingly, academics have paid scant attention to the role of the opposition. As Bingham Powell (2000: 97-98, 215) argues, it is true that when a "government has a solid majority and that majority has the cohesion usually necessary to sustain a parliamentary government, the representatives of the opposition party may have little impact on policy making”. But, as he also sates, when "political governing control conditions [...] encourage the incumbent government to negotiate with them" opposition parties have enhanced bargaining power to influence the final outcome of policies. It is clear that minority governments in parliamentary democracies represent one of these situations.

In our view, if parties in coalition cabinets have to give consent before a policy can be adopted, it should also be clear that (at least some) parties in opposition will have to do likewise in order to allow a minority government to adopt a policy. Therefore, one might expect that both executive and legislative coalitions (borrowing the terms of Laver and Schofield (1990)) should be given similar importance in the literature. However, we still have rather limited research to guide us in determining the extent to which the opposition is effectively represented in policy making (Bingham Powell, 2000: 93).

Only a few authors have explicitly considered this. For instance, Hallerberg et al. (2007) argue that the presence of possible alternative coalition partners in the opposition makes the threat to break up a governing coalition credible enough to enforce budget targets in ideologically diverse multiparty governments. However, this approach takes the threat as given and does not consider variation in the preferences of oppositions, which is what we do here. ${ }^{1}$ The annual 'test' of having the budget passed in parliament may be a suitable situation to enrich our knowledge about the role of the opposition in policy making. Provided that a minority cabinet is in office, it is reasonable to expect that the opposition's preferences on deficits -in interaction with the government's prioritieswill shape fiscal outcomes. This remains an intriguing issue on the political science agenda and it is what we will try to address in the following pages.

\footnotetext{
${ }^{1}$ For another example on the role of oppositions, see Ganghof and Bräuninger’s (2006) analysis of the level of accommodation of opposition parties as compared to government parties in Australia, Denmark, Finland, and Germany.
} 


\section{Argument and hypotheses}

Minority governments must bargain with the opposition to pass legislation (Bingham Powell, 2000). Hence, if opposition parties are required to agree on a new budget, it is hard to imagine that the final outcome will be unaffected by their preferences. Our argument leaves ideology aside (i.e. holds it constant), and sees parties in parliamentary opposition as rational actors who only care about winning office. ${ }^{2}$ Then the question is: When will opposition parties be interested in a deficit and when not?

The main goal of an opposition party is to take over government in the most favourable conditions. Hence, its decisions will be in line with this aim, including those on fiscal policy. This implies that when evaluating whether or not to accept a deficit budget, opposition parties will look at two different issues. On the one hand, they will evaluate the extent to which the budget outcome may help them win office (that is, harm the incumbent government). But on the other hand, parties are not myopic office seekers. They want to access power in favourable conditions in order to hold it as long as possible. Therefore, their behaviour will also be directed towards smoothing the conditions under which they will take over government. In summary, opposition parties have two main concerns: i) to avoid supporting budgets that do not increase their chances of making the current government fall, but also ii) to avoid those that worsen the conditions that they may eventually face when in government.

The first of these opposition's considerations has to do with the short-term consequences of deficits. Deficits are generally considered to reflect a mismanagement of resources and a signal of unstable governments. Although some authors have contended that deficits are necessary for countercyclical policies or public investment, it can generally be argued that, keeping the economic cycle constant, fiscal deficits are negative because they increase debt, inflation, interest rates, and current account deficit. To avoid such unsustainable economic paths, the strength and stability of the

\footnotetext{
${ }^{2}$ Notwithstanding this theoretical license, we control for the possible effect of ideology in our empirical analyses. This is because we want to isolate the effect of our substantial variables in the statistical contrast.
} 
government is thought to be a relevant variable. Politically weak governments tend to be considered as less able to undergo economic stabilisation and successful adjustment policies (Locke and Ahmadi-Esfahani, 1998; Franzese, 2002). Many authors have indeed shown how unstable and weak governments are more prone to deficits and debt, particularly in problematic economic contexts (de Haan and Sturm, 1994; Borrelli and Royed, 1995; de Haan et al., 1999; Lavigne, 2010). We will thus consider that if a government falls into deficit, this will signal it as being weak. Similarly, deficits may also indicate that the economy is undergoing a crisis. In this regard, Duch and Stevenson (2008) have shown that voters are not neutral to the contextual economic conditions, making governments accountable through more or less intense sanction voting.

Hence, as elections are a retrospective accountability mechanism (Fiorina, 1981; Ferejohn, 1986), ${ }^{3}$ voters will punish the unbalanced management of resources by parties in government. In fact, despite the conventional wisdom is that expansionary fiscal policy help incumbents get reelected, when it comes to the data the opposite tends to be the case. Peltzman (1992) -in the United States-, Brender (2003) -in Israel-, or Drazen and Eslava (2010) -in Colombia- reported that in general voters prefer fiscal frugality and punish rather than reward loose fiscal policies, at least at the state and local levels. Moving to a large-cross section of countries and at the national level, Brender and Drazen (2008) found no evidence that deficits help for reelection. And what is more, in their reduced sample of developed countries (and especially in old democracies), deficits over the term of office and also in election years happened to decrease the probability that incumbents get reelected. From the opposition's perspective, this will clearly be a positive outcome. ${ }^{4}$

However, deficits do also have long-term consequences. Every deficit outcome today builds up a debt that needs to be paid in the future, plus the accumulated rate of interest. This can be a burden for the opposition parties if they expect to win government in the

\footnotetext{
${ }^{3}$ Recall that parties in office and in opposition are considered to be ideologically equal, so voters are assumed to vote beyond these considerations.

${ }^{4}$ We can assume that electoral sanctions to government parties will be voters' electoral reward for opposition parties. It is true that voters may also blame the opposition for falling into a deficit since its consent is indispensable when a minority cabinet rules. Nonetheless, we assume throughout the paper that it is the government who receives the electoral sanction, at least more than opposition parties. This is coherent with retrospective voting theories, which generally imply that voting is a sort of referendum on the government's performance; a vote for the opposition being the way to penalise it.
} 
near future. Altig and Davis (1989) show, for instance, how higher levels of debt constrain the distributive calculations of governments. Likewise, Alesina and Tabellini (1990) also emphasise the inter-temporal effects of debt as a way to influence the policy making of future governments. Hence, future government holders will prefer to access office with the lower levels of debt possible, because this will give them more autonomy in their policy making.

As a result of all this, when opposition parties are required to pass a budget, they will face a trade-off. On the one hand, deficits could produce short-term benefits to them. They may harm the incumbent government signalling its weakness and the poor state of the economy, and foster electoral sanctions. That would increase opposition parties' chances of being in the next cabinet. On the other hand, parties in opposition will also take into account the shadow cast by the future. A deficit today increases debt tomorrow, which can be a long-term burden that they will prefer to avoid. ${ }^{5}$ Given this trade-off, our whole argument revolves around identifying the conditions under which the balance is tipped in favour of the short or long-term elements of the inter-temporal dilemma that opposition parties face. In particular, we propose two factors: the concentration of the opposition and the fragmentation of the minority government.

In developing our argument, we will first consider the concentration of the opposition. Everything else the same, the more concentrated the opposition is in a single party, the higher the probability that it will be part of a future government and, in addition, the more likely it will hold it alone. This has both short and long-term implications. In a short-term calculus, when an opposition is concentrated in a single party, the electoral reward of voters' sanction to government will predominantly benefit this party. However, in the long term, the more concentrated the opposition, the more likely it will have to deal (alone) with tomorrow's debt when in government.

On the other hand, these costs and benefits do not depend simply on the composition of the opposition. The type of minority government in office can also make deficits more or less profitable from the opposition's perspective. Thus, the second factor we take into

\footnotetext{
${ }^{5}$ On the government's side, decisions regarding the use of deficits and debt have been also seen as intertemporal strategic devices by authors like Alesina and Tabellini (1990) or Persson and Svensson (1989). For an empirical test of their hypotheses, see Pettersson-Lidbom (2001).
} 
account is the level of fragmentation within government. From the perspective of opposition parties, what matters is whether or not a deficit harms the government, giving them the opportunity of fighting in an election they can win. According to Strøm (1990), the higher the fragmentation of a government, the more likely it will fall under traumatic circumstances. Hence, a fragmented minority government will find it hard to survive budgetary deficits and, more generally, economic crises.

We contend here that parties in opposition are interested in deficits in the short term because they signal the government as weak. Thus, if the latter is more fragmented it will make deficits even more attractive. A higher fragmentation within the government would, as a result, tend to tip the balance in favour of the first part of the trade-off making opposition parties more prone to accept deficits. On the other hand, a low fragmented minority government would find it relatively easy to deal with a deficit, making the fall of the government less likely. As previous scholars have shown, this type of cabinet does not have to reconcile internal heterogeneous preferences, being both less likely to run budget deficits and more able to cope with them in the event that they are produced. Hence, a concentrated opposition will push for a more balanced budget that would leave the fiscal accounts in a better shape for the next term.

As a consequence, and considering all the things said to this point, (i) the more concentrated an opposition, the more each of its parties will be interested in the shortterm benefits of deficits if the government is already a fragile one (namely, fragmented), but (ii) if the government is strong enough (i.e. not fragmented), a highly concentrated opposition will make the long-term costs of deficits weigh more. Thus, the effect of concentration in opposition runs in two opposite directions depending on the type of minority government they face. This leads us to pose two conditional hypotheses to be tested empirically:

Hypothesis 1: When a low fragmented minority government is in office, higher concentration of the opposition decreases the likelihood of deficits.

Hypothesis 2: When a highly fragmented minority government is in office, higher concentration of the opposition increases the likelihood of deficits. 


\section{Data and methodology}

Most of the data used in this paper is drawn from two different databases. In the first place, most political variables are taken from the Database of Political Institutions (DPI: Beck et al., 2001). The remaining variables, mostly economic, come from the Comparative Political Data Set (CPDS: Armingeon et al., 2005). We concentrate our research on the period for which we have all the relevant data (1976-2000). Our full sample covers twelve parliamentary OECD democracies. ${ }^{6}$

This work is substantively interested in how several political variables (related to government's and opposition's characteristics) affect the national accounts in terms of the production of deficits. Hence, the empirical dependent variable used in all the statistical analyses is the annual deficit (primary government balance) as a percentage of GDP, taken from the OECD Economic Outlook Database as compiled in the CPDS. To ease the interpretation of the regression parameters, we have recoded the original variable so that it is positive when there is a deficit, and negative when there is a budget surplus.

We use two key independent variables to explain the way oppositions affect budget deficits. First, we need to account for the Concentration in Opposition. As this is the crucial variable in this article, we do not want our results to be driven by the choice of a specific measure and thus we use three different ones. Each of them captures different sides of the same phenomenon: whether the parties in opposition perceive as likely that they will be the ones taking over governmental responsibilities alone when the current cabinet terminates.

- Herfindahl Index (HI): this index is typically used to measure the degree of industrial concentration. In our case, it is calculated as the sum of the squared

\footnotetext{
${ }^{6}$ We concentrate on parliamentary democracies, because it is where oppositions are salient and relevant. Moreover, there is a large literature that shows that in presidential countries, compared to parliamentary ones, the interests of the legislators will be often much more divergent from the interest of the presidential candidates. On the other hand, in parliamentary democracies party discipline tends to be higher, and we are specifically interested in the behaviour of government and opposition parties as unitary actors. The sample is limited to the twelve countries for which we have data for all the variables we include in the analyses: Austria, Belgium, Canada, Denmark, Germany, Ireland, Italy, Netherlands, New Zealand, Norway, Sweden, and United Kingdom.
} 
seat shares of all parties in opposition. The higher the resulting value, the higher the concentration.

- Picking Probability Index (PPI): this measure is based on the probability that two legislators picked at random from the whole parliamentary opposition will belong to the same party. Again, the higher the index, the higher the concentration.

- Largest Opposition Party Size (LOPS): this variable directly captures the size of the largest opposition party through the share of opposition seats it holds in Parliament. Obviously, the larger the party, the more concentrated the opposition will be. ${ }^{7}$

Hence, all variables are an increasing measure of opposition's concentration. As said, the reason why we offer the analyses with three different measures of our main independent variable is to provide enough robustness checks to be confident in the empirical results.

Secondly, we have to account for the influence of the type of government on deficits. In our opinion this question has been unsatisfactorily answered in the empirical literature because of the wide variety of approaches and results. As presented in the argument, we want to distinguish minority cabinets by their strength, which we have claimed to be related to fragmentation. We have assumed that a logical cut-off point is whether the cabinet is held by a single party minority government or by a coalition minority government. In the former, party unity acts as glue that keeps the government stronger vis à vis difficulties. However, in coalition governments, different preferences have to be reconciled. Therefore, it is more likely that they behave fiscally loosely to satisfy different constituencies and, in case they need to adjust, they will be more prone to disagree and cause the government to fall. We analyse the performance of these types of governments in comparison to majority cabinets (using single party majority governments as a reference category and controlling for coalition majority governments). ${ }^{8}$ The potential influence of the opposition on minority governments is also restricted by how far the government is from a majority. Then, the variable margin

\footnotetext{
${ }^{7}$ We have also used another version of this variable (LOPS), by calculating the size of the largest opposition party directly through its seat share in Parliament. The results are basically similar. ${ }^{8}$ Due to the reduced number of cases and lack of clear theoretical expectations, caretaker governments are not included in the statistical analyses.
} 
to absolute majority is the percentage of seats that the sum of parties in the minority government need to achieve the threshold of the absolute majority (taking the value 0 if all parties in office sum $50 \%$ or more of the seats).

To properly account for the influence of the previous government and opposition variables and isolate their causal effect, we include sets of different controls. First, we account for economic variables and the most commonly recognised as automatic stabilisers (Roubini and Sachs, 1989): (1) the previous year deficit, in order to isolate unitarily the main autoregressive component of the model, (2) the annual real GDP growth as a natural smoother of deficits, ${ }^{9}$ (3) long-term interest rates as the price that governments pay for the current debt and expect to pay for a deficit, (4) the unemployment rate, since it expresses the possible economic and social circumstances of a country that may extraordinarily impel budget deficits in a specific year, ${ }^{10}$ (5) openness (trade and capital restrictions), since increased international economic exposure undermines the stabilization function of fiscal policy and fiscal regulation (Jensen and Jensen, 1995). We operationalise this last variable as the sum of two indexes of the Comparative Political Data Set: an index of the restrictions on payments and receipts of goods and invisibles (which ranges from 0 to 8) and an index of the restrictions on payments and receipts of capital (which ranges from 0 to 4). This gives as a total account of the openness of the economy.

The second set of control variables addresses the issue of political opportunism and stability. First, we consider the incentives to spend when elections are close. There is an large theoretical literature on political budget cycles (e.g. Alesina et al., 1993, 1997; or Alesina and Roubini, 2008), while empirically there is inconclusive evidence on them (Andrikopoulos et al., 2004). Including this variable, we avoid the potential bias caused by governments' tendency to increase deficit-financed expenditures just before elections. ${ }^{11}$ Apart from budget cycles, this variable also controls for the possibility that

\footnotetext{
${ }^{9}$ Here we only consider this direction of the causal relationship as a control, although it is true that fiscal policy may well affect GDP growth in the first place (see for instance Romero-Ávila and Strauch, 2008; or Afonso and Furceri, 2010).

${ }^{10}$ This is the unemployment series standardised for comparison as provided by the CPDS. For those observations for which the OECD did not provide the standardised unemployment rate, we used the unstandardised one (the correlation between the two is 0.98).

${ }^{11}$ It is true that manipulation of fiscal policy in election years need not be reflected in the overall deficit but only in the spending composition (see for instance Vergne, 2009). Nonetheless, we believe it is a relevant control for our models.
} 
minority governments were more likely during election years. ${ }^{12}$ Although the standard procedure is to include a dummy of whether elections were called in a given year, there are potential problems associated with that approach. Take, for instance, the case in which an election takes place in January. The afore-mentioned method would code that year as a whole electoral year despite the fact that only one of its months was a preelectoral one. Instead, we have calculated the pre-electoral year share, that is, the share of each year that belongs to the 365 days previous to an election, which should better capture the influence of elections on spending incentives. ${ }^{13}$

In addition, we include the number of changes in government in each year to account for the general political instability in the country, assessing whether or not unstable environments, in which the members of the cabinet may feel insecure with their posts, lead to higher deficits. We also control for the potential influence of the disproportionality of the electoral system. ${ }^{14}$ Governments in non-proportional systems are said to spend less (Milesi-Ferretti et al., 2002) and produce fewer deficits (Persson and Tabellini, 2004).

Another set of control variables reflects the incentives of governments to increase their spending. We first include a dichotomous variable that takes value 1 if there are one or more parties in the executive representing special interests (regionalists, nationalists, religious, or rural parties), and 0 otherwise. The rationale is that these parties have more incentives to spend public resources on specific constituencies and, therefore, will be less fiscally responsible. The partisanship of the cabinet is also taken into account. Right-wing cabinets are taken as reference category. This way we can analyze two possible partisanship effects. First, by including a dummy variable for left cabinets, we can control for the claim that leftist governments either fall more frequently into deficits or undertake less fiscal adjustments (Volkerink and de Haan (2001) show this is the case, at least in the seventies). In addition, following Laver and Shepsle (1990, 1996), a variable for centre cabinets is also included in the analysis. Their argument is that centre governments tend to hold the median position in the legislature and therefore,

\footnotetext{
${ }^{12}$ Nevertheless, this endogeneity problem is rather unlikely to be present since the correlation between minority governments and election years is almost zero.

${ }^{13}$ We want to thank a reviewer for this suggestion, which we believe is theoretically more sound than introducing the standard dummy for an electoral year.

${ }^{14}$ Index of disproportionality according to the formula (least squares) proposed by Gallagher (1991).
} 
even in a minority cabinet, can pit the interests of left and right parties in the opposition against each other and be more able to pass the budget they prefer.

Finally, we also need to control for the contextual dimension in deficits. Around the early nineties, deficits were systematically reduced in all countries. ${ }^{15}$ Therefore, it is relevant to account for the context that can undermine or strengthen the political and economic incentives to fall into deficit. A context requiring more fiscal responsibility increases the constraints faced by bargaining parties and thus makes the game of domestic politics less relevant for deficit production. In this regard, Persson and Tabellini (2003: 179) claimed that the 1990s were a time of "budgetary consolidation" as opposed to previous decades. From then on, international organisations promoted adjustment programmes and supranational integration required convergence and balanced budgets, consolidating a non-deficit paradigm all over the developed world (Stiglitz, 2002; DeLong and Eichengreen, 2002; Simmons et al., 2006). ${ }^{16}$

In a similar vein, Hallerberg et al. (2004, 2007) showed that given this timeidiosyncratic conditions which make policy-makers (and also voters) more deficitaverse, European countries centralised budget decision-making procedures in order to be able to cut deficits down (see also Lavigne, 2010). To control for these contextual conditions, we include in all the analyses Braüninger and Hallerberg's (2006) forms of fiscal governance, ${ }^{17}$ which account for the rules by which fiscal decisions are adopted in a government. This variable shows an increasing trend to more centralisation of the fiscal decisions from the nineties on. It thus lets us control for the change in the policy paradigm regarding deficits, by which the decisions on budget balances are centralised to encourage fiscal stringency. The variable has three categories: Fiefdom (which is the reference category in the models), Delegation, and Contract. ${ }^{18}$ We have taken the descriptions and coding of these variables from Bräuninger and Hallerberg (2006). ${ }^{19}$

\footnotetext{
${ }^{15}$ For example, in a sample of twenty-three OECD countries included in the Comparative Political Data Set, before 1993 the average budget deficit is almost 1\%. For the period 1994-2004, the average was around a $1.5 \%$ surplus.

${ }^{16}$ This is in line with the contributions made by the literature on international diffusion of policies which claims that globalisation implies an imitation model that fosters the application of similar orthodox policies (see for instance Przeworski and Meseguer, 2002; or Simmons et al., 2006).

${ }^{17}$ The coding rules of this variable come from Hallerberg (2004) and are based upon interviews for the book as well as earlier versions that appeared in Hallerberg and von Hagen (1999) and Hallerberg et al. (2001).

${ }^{18}$ Fiefdom refers to the situation in which the full cabinet makes budget decisions, and in practice ministers support each other's budget bids so that they generally get what they want. Under delegation,
} 
Regarding the methodology, the statistical models are the commonly used time-series cross-sectional ordinary least squares regressions with panel-corrected standard errors (Beck and Katz, 1992), controlling for the fact that the deficit-generating process is notably dynamic with a Lagged Dependent Variable (LDV) model. ${ }^{20}$ Authors like Beck and Katz (2004) or Keele and Kelly (2006) make a case for the parsimony of LDV models compared to others. Fixed-country effects are included in the specifications of all the econometric models to control for how institutional differences across countries (those not already included in the models) might affect governments' budget balances. ${ }^{21}$ Finally, to control for any remaining time effects and different propensities to generate deficits over time, we also incorporate year dummies in all models.

\section{Results}

To recap, this paper has focused on how opposition parties' preferences affect deficit outcomes when the government is in a minority. We have claimed that their preferences are defined by their perceived probability of having to deal with the future burden of deficit. We also claim that this effect is conditional on the type of minority government in office. The statistical tests of the argument yield the estimations presented in Table 1. We run three different models with each of the three different measures of concentration

spending ministers delegate budget-making powers to a central player, the finance minister. She centralises the budget-making process, with negotiations generally taking place bilaterally between the finance minister and any spending minister. In this scenario, spending ministers have much less say over their final budget allocation. In the latter case, known as contracts, the political parties commit themselves to spending targets for the life of the government. The agreement includes detailed rules that explain what changes are to be made to the budget given changing macroeconomic conditions. In this case, the ministers are, in effect, simply managers of budgets that the agreement already sets.

${ }^{19}$ We could have opted for even more detailed measures regarding budgetary institutions (see the electronic appendix of Hallerberg et al., (2007)). However, for these measures we only had very few points in time available (1991, 2001, and 2004). Given that our time scope ranges from 1976 to 2000, we clearly needed the temporal variation that the coding of the forms of fiscal governance that we finally used gave us. Besides, we believe the latter variable nicely summarizes many important features of the budget process.

${ }^{20}$ Since Durbin-Watson and Drukker (2003) tests showed that there was some serial autocorrelation, we control for panel-specific AR1 autocorrelation structure.

${ }^{21}$ Hausman tests were run and revealed that it was not possible to assume random effects for all models, although the coefficients of the substantively interesting variables were similar in both fixed and random effects specifications. As Beck (2005) argues, in dynamic panel models (with LDV) and fixed effects, it is well known that the fixed effects will downwardly bias the coefficient of the independent variables. This is known as Hurwicz or Nickell bias (see also Nickell 1981), but according to Beck (2005), the problem is much less serious for TSCS data as compared to panel data, especially when the number of years in the sample is reasonably high; as it is in our case. 
in the opposition, what gives a total of nine columns. The first model displays the full specification without the substantively relevant interactions. In the second model, we provide the interactions between the type of minority government and each measure of opposition's concentration. Finally, as a robustness check, the third model presents a more parsimonious specification run only with the significant controls apart from the variables of interest.

\section{[TABLE 1 ABOUT HERE]}

Firstly, a brief comment on the control variables is in order. In general they perform as expected in the literature (see for instance Bohn, 1998). Higher economic growth makes deficits less likely by acting as an automatic economic stabiliser. Growth increases governments' revenue as a consequence of more intense economic activity in the country. The opposite effect results from increasing unemployment rates, since governments find themselves required to spend more in compensation payments. In accordance to Knot and de Haan (1995), we also find a negative relation between higher interest rates and deficits, as the latter can crowd out national saving and pressure upwards the former. Openness, on the other hand, is the only economic variable that does not reach conventional levels of significance.

The estimates for the variables capturing the fiscal governance form are highly significant and in the expected negative direction. Delegation and contract (as opposed to fiefdom) serve as a means towards fiscal discipline, as argued in Bräuninger and Hallerberg (2006). ${ }^{22}$

Among the political control variables, only the number of changes in government shows a statistically significant effect as, quite logically, instability and deficit production go hand in hand. The effect of executives' partisanship, in its two versions (left government and special interests), has the expected sign, but does not reach standard levels of statistical confidence, confirming previous findings that show that partisanship is not a crucial determinant of deficits (de Haan and Sturm, 1997; Heller, 1997).

\footnotetext{
${ }^{22}$ A Wald test yields that, although the Delegation coefficient is higher than the Contract one, both coefficients are not statistically different at the $95 \%$ level of confidence. Hence, both fiscal decision institutions are clearly superior to Fiefdom in terms of deficits, but Delegation cannot be said to be better than Contract at reducing deficits.
} 
Likewise, in the full models we find no evidence in favour of Laver and Shepsle's $(1990,1996)$ argument on the influence of centre cabinets' pivotal role in the generation of fiscal (im)balances. We do however find a significantly positive effect in the more parsimonious specification. Finally no relationship between proportionality of electoral rules and budget deficits appears to emerge either.

Yet the most relevant political variables for the aim of this study are the type of government and opposition, which relate to our hypotheses. As it can be seen in the first model, having a single party minority government does not exert any statistically significant effect on the likelihood or magnitude of a deficit compared to single party majority governments. Strikingly, these first findings go in the opposite direction of many previous studies that have supported the weak government thesis. Our interpretation of this evidence is that, whereas it may be true that minority governments have to satisfy more constituencies than their own and therefore probably increase spending, it is also true that they will face more checks in doing so, especially if faced with a deficit-averse opposition. On the other hand, a single party majority cabinet (the reference category) might be more proficient at keeping spending down, but it may also encounter fewer constraints than other types of governments to run deficits in case they need them. The fact that these two effects may cancel each other out might explain the lack of differences between single party majorities and minorities. ${ }^{23}$

The story for coalition minority governments is rather different though. As compared to single party majority cabinets, non-majoritarian coalitions seem to produce higher deficits. ${ }^{24}$ This can be seen in model 1 . This finding would be in line with the studies that predict minority governments and coalitions to be more unstable and prone to fiscal mismanagement. However, this article hypothesises that the effect of any minority government on deficits should be conditional on the structure of parliamentary opposition. This mutual influence arises because minority governments need the support of a part of the opposition to pass a budget, and, at the same time, the incentives of

\footnotetext{
${ }^{23}$ In normative terms, these results support Strøm's $(1985,1990)$ challenge of the conventional view when he stresses that minority governments can be said to leave a surprisingly favourable impression when their record is analysed. "At the very least, it is not clear that the[ir] bottom line is negative, either for parties considering participation in such cabinets or for the political system as a whole" (Strøm, 1990: 131).

${ }^{24}$ This is somewhat further supported by the positive coefficient of the variable Coalition Majority Cabinet, although it is only statistically significant in the models with the interactions.
} 
oppositions to behave in a certain way (more or less cooperative/belligerent with respect to budget deficit outcomes) depend on the characteristics of the other bargaining side (the minority government).

This conditional argument of the opposition's role is tested in model 2, which provides empirical support to it. In the first place, we can observe the interactive effect with coalition minority governments. The principal component is not significant anymore. That is, when the opposition is totally fragmented, these executives are not significantly different to single party majority governments as regards the production of deficits. The effect found in model 1 seems to be entirely due to the role of opposition concentration, which is normally overlooked as a relevant actor. As we can see, the interaction Minority Government (Coalition) * Concentration in Opposition is consistently highly positive and significant in the three specifications of the opposition variable. In other words, only when the opposition's concentration increases, coalition minority governments tend to run higher deficits. Hence, it appears that when a minority government is fragmented (namely, weaker), then a concentrated opposition is especially interested in pushing the executive to fall into deficit despite its intertemporal calculus of possibly having to pay the future debt.

The other part of our argument is captured by the interaction Minority Government (Single Party) * Concentration in Opposition. The negative and statistically significant coefficient estimates in their three specifications suggest that, when concentrated oppositions face single party minority governments, they weigh the long-term negative effects as being more important than the short-term benefits of passing a deficit budget bill. This is well in line with the expectation derived from the first hypothesis.

To account for the stability and robustness of the estimations, we run a third model in which we drop the non-significant variables. As it can be seen, the magnitude of the effects and their level of significance remain quite similar. Moreover, dropping one by one the insignificant variables, centre executives gain significance. More importantly, the interactions between types of minority governments and opposition concentration keep their significance levels and magnitude, and, if anything, they are strengthened. 
Although the information offered in the tables might be clear enough, following Brambor et al.'s (2006) guidelines, it is also useful to provide the graphical results,. This helps assessing the significance of the effects for the whole range of values of the main independent variables. We take the specifications of model 3 (the parsimonious model) using the Herfindahl index as the measure of opposition's concentration. ${ }^{25}$

\section{[FIGURE 1 ABOUT HERE]}

\section{[FIGURE 2 ABOUT HERE]}

The two figures above clearly show the interactive effects of interest. The two marginal effects' lines have divergent slopes as a result of the different conditional effect of opposition's concentration on deficits depending on the particular type of minority government in office. In Figure 1 we can see that under single party minority cabinets, concentration in opposition has a negative effect on deficits. A change from the minimum value of our index to its maximum entails around a 3\% expected reduction in deficit (from an average increase of the deficit of almost $2 \%$ to an average reduction of over $1 \%$ ), compared to single party majority governments (the reference category). ${ }^{26}$

Opposition's concentration has the reverse effect when a minority coalition is in office. In general, decreasing fragmentation of the opposition in this scenario makes the production of budget deficits more likely. In Figure 2, the predicted value of our dependent variable changes from a slight deficit reduction to an average deficit increase of over $5 \%$ in response to a change from the minimum to the maximum value of opposition's concentration.

To account for the reliability and robustness of the previous results we have undergone two further tests. Firstly, we have rerun the analyses above keeping only the minority governments in the sample. The previous analyses were actually showing the interactive effects of minority governments and oppositions compared to the deficit outcomes of single party majority governments, which were the reference category. Here, we want to

\footnotetext{
25 The figures are highly similar with either of the other two variables measuring the concentration in opposition. These figures are available upon request.

${ }^{26}$ In interpreting these graphs, we must recall that the deficit variable is coded to make it increase with deficits. That is, a deficit is coded as positive and a surplus as negative.
} 
evaluate the effect of opposition concentration by looking at minority governments only, comparing coalition and single party cabinets. That is what we do in Table 2 by restricting the sample to minority governments. As this sample is substantially smaller than the full sample, we run the reduced model (model 3) without year dummies (which after controlling for the form of fiscal governance are always insignificant) so as to keep some degrees of freedom more. ${ }^{27}$ Although due to the reduced number of observations some control variables lose their statistical significance, the results concerning oppositions go in the expected direction. The interaction between coalition minority governments and opposition's concentration is positive and significant, which implies that a concentrated opposition will be more likely to concede deficits if the government is a minority coalition rather than a single party minority one.

\section{[TABLE 2 ABOUT HERE]}

Secondly, to test to which extent our results are driven by the influence of specific outliers, we have generated an added-variable plot on the results of Table 2. More concretely, we plot the effect, observation by observation, of our independent variable of interest (in this case, the interaction between type of minority government and opposition concentration) in order to see if the slope is decisively driven by concrete minority governments. Figure 3 shows the plot for the model with the Herfindahl index as a measure of opposition concentration. ${ }^{28}$ As it can be seen, the scatter follows a positive slope (positive and significant effect; $\mathrm{t}=2.32$ ) and there are no clear problematic observations. $^{29}$

\section{[FIGURE 3 ABOUT HERE]}

These robustness checks come to further support the evidence shown previously. Consistent with our argument, therefore, opposition parties seem to be key in explaining fiscal deficits when a minority government is in office, though in ways that are not

\footnotetext{
${ }^{27}$ As one can see, the analyses are run on 69 observations, what means that about a $27 \%$ of the 'countryyears' in our full sample are considered to be under the rule of a minority government.

${ }^{28}$ We use the Herfindahl index to be consistent with Figures 1 and 2, but the plots with the other measures of concentration are very similar.

${ }^{29}$ It is true that in the upper part of the graph there are two observations that could be seen as potential outliers pushing the positive relation (Denmark 1992, and Sweden 1982). All the empirical analyses have been rerun dropping these cases and they remain essentially unchanged. We have also analysed the residuals and they seem to follow no systematic pattern.
} 
immediately apparent. Concentrated oppositions push multiparty minority cabinets to fall into higher deficits. However, they would not allow a single party office to do so in order to be in a good position in the event they win office in the following elections.

\section{Concluding remarks}

The argument presented in this paper makes a case for taking into consideration the opposition's incentives and far-sightedness. Whereas it is true that a non-myopic opposition will take into account the future damage that a current deficit may cause, it is also true that it will encounter a tension with its potential short-term benefits (weakening the current government, for instance).

Empirically we have shown that when the opposition's support is required to pass the budget, it will push for deficits if it is sufficiently concentrated and it is contesting a fragile government. We theorised that this happens because such a government can be weakened by running a deficit so that parties in opposition can benefit from the electorate's reaction without having to share much among them. However, if the minority government is stronger (which we relate to single party governments), then the opposition will take the future burden of debt more into consideration. In such a situation, the more likely the opposition believes it will rule in the next legislature, the more they will push for non-deficit outcomes as they want to avoid paying the future debt.

As a corollary, we believe that this study contributes to previous research in the field through the analysis of budget deficits considering not only the governmental actor, but oppositions and their rational calculi as well. Whenever an opposition is required in order to pass the budget, its preferences should be reflected in the final outcome. We believe this framework could be extended to the study of other areas of governmental action and show when the opposition might be able to impose its preferences. In addition, we also think that this kind of reasoning might also be applicable to all those contexts where more than one party has to give consent to a deficit production. In coalition governments different parties might have different inter-temporal concerns and, depending on the extent to which they believe they will participate in future 
governments, they may push for a particular outcome in one direction or the other. More qualitative evidence on the preferences and rationale behind oppositions' decision-making could also be provided to complement the findings hitherto presented. In sum, we believe that this paper may provide promising paths for future research.

\section{Acknowledgements}

Previous versions of this paper were presented at the Political Science Graduate Workshop in Nuffield College (University of Oxford), and the 2nd ECPR Graduate Conference in Barcelona. We want to thank all the participants as well as José M. Maravall, Marek Hanusch, Javier Arregui, and the anonymous reviewers for their very valuable comments. The usual disclaimer applies.

\section{References}

Afonso, A., Furceri, D., 2010. Government size, composition, volatility and economic growth. European Journal of Political Economy, In Press, Corrected Proof, Available online 6 March 2010.

Alesina, A., Tabellini, G., 1990. A positive theory of fiscal deficits and government debt. The Review of Economic Studies 57, 403-414.

Alesina, A., Tabellini, G., Cohen, G.D., 1997. Political cycles and the macroeconomy, Chapter 9. MIT Press, Cambridge, MA.

Alesina, A., Cohen G.D., Roubini, N., 1992. Macroeconomic policy and elections in OECD democracies. Economics and Politics 4, 1-30.

Alesina, A., Cohen G. D., Roubini, N., 1993. Electoral business cycle in industrial democracies. European Journal of Political Economy 9, 1-23.

Alesina, A., Roubini, N., 2008. Political cycles in OECD economies. National Bureau of Economic Research (NBER), W3478.

Alt, J. E., Lowry, R. C., 1994. Divided government, fiscal institutions, and budget deficits: evidence from the states. American Political Science Review 88, 81128.

Altig, D., Davis, S. J., 1989. Government debt, redistributive fiscal policies, and the 
interaction between borrowing constraints and intergenerational altruism. Journal of Monetary Economics 24, 3-29.

Andrikopoulos, A., Loizides, I., Prodromidis, K., 2004. Fiscal policy and political business cycles in the EU. European Journal of Political Economy 20, 125-52.

Armingeon, K., Leimgruber, P., Beyeler, M., Menegale, S., 2005. Comparative Political Data Set.

Barro, R. J., 1979. On the determination of public debt. Journal of Political Economy 87, 940-971.

Beck, N., 2005. Time Series Cross-Section Data - Dynamics - Continuous. (Lecture notes).

Beck, T., Clarke, G., Groff, A., Keefer, P., Walsh, P., 2001. New tools in comparative political economy: The Database of Political Institutions. World Bank Economic Review 15, 165-176.

Beck, N., Katz, J.N., 1992. What to do (and not to do) with time-series cross-section data. American Political Science Review 89, 634-47.

Beck, N., Katz, J.N., 2004. Time Series-Cross Section Issues: Dynamics, 2004. Working Paper, July 24, 2004.

Bingham Powell, G., 2000. Elections as instruments of democracy: majoritarian and proportional visions. Yale University Press, New Haven.

Bohn, H., 1998. The behavior of U.S. public debt and deficits. The Quarterly Journal of Economics 113, 949-963.

Borge, L.-E., 2005. Strong politicians, small deficits: evidence from Norwegian local governments. European Journal of Political Economy 21, 325-44.

Borrelli, S. A., Royed, T. J., 1995. Government 'strength' and budget deficits in advanced democracies. European Journal of Political Research 28, 225-260.

Brambor, T., Clark, W.R., Golder, M., 2006. Understanding interaction models: improving empirical analyses. Political Analysis 14, 63-82.

Bravo, A., Silvestre, A., 2002. Intertemporal sustainability of fiscal policies: some tests for European countries. European Journal of Political Economy 18, 517-28.

Bräuninger, T., Hallerberg, M., 2006. Monetary unions and domestic policy reforms: cabinet decision-making and policy outcomes in European Union countries prior to EMU, conference paper presented at the First World Meeting of the Public Choice Society, Amsterdam, 29 March - 1 April, 2007.

Brender, A., 2003. The effect of fiscal performance on local government election results 
in Israel: 1989-1998. Journal of Public Economics 87, 2187-2205.

Brender, A., Drazen, A., 2008. How do budget deficits and economic growth affect reelection prospects? Evidence from a large panel of countries. American Economic Review 98, 2003-2220.

D'Alimonte, R., 1978. Competizione elettorale e rendimiento politico: il caso italiano. Rivista Italiana di Scienza Politica 8, 457-493.

DeLong, B., Eichengreen, B., 2002. Between meltdown and moral hazard: the international monetary and financial policies of the Clinton administration, in: Frankel, J.A., Orszag, P.R. (Eds.), American Economic Policy in the 1990s. MIT Press, Cambridge.

Dodd, L. C., 1976. Coalitions in parliamentary government. Princeton University Press, Princeton.

Drazen, A., Eslava, M., 2010. Electoral manipulation via voter-friendly spending: Theory and evidence. Journal of Development Economics 92, 39-52.

Drukker, D. M., 2003. Testing for serial correlation in linear panel-data models. Stata Journal 3, 168-177.

Duch, R. M., Stevenson, R. T., 2008. The economic vote: how political and economic institutions condition election results.

Edin, P.-A. Ohlsson, H, 1991. Political determinants of budget deficits: coalition effects vs. minority effects. European Economic Review 35, 1597-1603.

Edwards, S., Tabellini, G., 1991. Explaining fiscal policies and inflation in developing countries. Journal of International Money and Finance 10, 516-548.

Ferejohn, J., 1986. Incumbent performance and electoral control. Public Choice 50, 525.

Fiorina, M. A., 1981. Retrospective voting in American national elections. Yale University Press, New Haven.

Franzese, R. J., 2002. Macroeconomic policies of developed democracies. Cambridge University Press, Cambridge.

Gallagher, M., 1991. Proportionality, disproportionality and electoral systems. Electoral Studies 10, 33-51.

Ganghof, S., Bräuninger, T., 2006. Government status and legislative behaviour: partisan veto players in Australia, Denmark, Finland and Germany. Party Politics 12, 521-39.

Grilli, V., Masciandaro, D., Tabellini, G., 1991. Political and monetary institutions and 
public financial policies in the industrial countries. Economic Policy 6, 342-392. de Haan, J., Sturm, J.-E., 1997. Political and economic determinants of OECD budget deficits and governments expenditures: a reinvestigation. European Journal of Political Economy 13, 739-750.

de Haan, J., Sturm, J.-E., 1994. Political and institutional determinants of fiscal policy in the European Community. Public Choice 80, 157-172.

de Haan, J., Sturm, J.-E., Beekhuis, G., 1999. The weak government thesis: some new evidence. Public Choice 101, 163-176.

Hallerberg, M., 2004. Domestic budgets in a united europe: fiscal governance from the end of Bretton Woods to EMU. Cornell University Press, Ithaca, NY.

Hallerberg, M., von Hagen, J., 1999. Electoral institutions, cabinet negotiations, and budget deficits within the European Union, in: Poterba, J., von Hagen, J. (Eds.), Fiscal Institutions and Fiscal Performance. University of Chicago Press, Chicago, pp. 209-232.

Hallerberg, M., Strauch, R., von Hagen, J., 2004. Budgeting in Europe after Maastricht: patterns of reforms and their effectiveness. Hacienda Pública Espan 16\%a 201-25.

Hallerberg, M., Strauch, R., von Hagen, J., 2007. The design of fiscal rules and forms of governance in European Union countries. European Journal of Political Economy 23, 338-59.

Hallerberg, M., Strauch, R., von Hagen, J., 2001. The use and effectiveness of budgetary rules and norms in EU member states. Report Prepared for the Dutch Ministry of Finance.

Heller, W. B., 1997. Bicameralism and budget deficits: the effect of parliamentary structure on government spending. Legislative Studies Quarterly 22, 485-516.

Jensen, S.E.H, and Jensen, L.G., 1995. Debt, deficits and transition to EMU: a small country analysis. European Journal of Political Economy 11, 3-25.

Jones, B. D., True, J. L., Baumgartner, F.R., 1997. Does incrementalism stem from political consensus or from institutional gridlock? American Journal of Political Science 41, 1319-1339.

Keele, L. J., Kelly, N. J., 2006. Dynamic models for dynamic theories: the ins and outs of lagged dependent variables. Political Analysis 14, 186-205.

Knot, K. and de Haan, J., 1995. Fiscal policy and interest rates in the European Community. European Journal of Political Economy 11, 171-87. 
Laver, M. J., Schofield, N., 1990. Multiparty government: the politics of coalition in Europe. Oxford University Press, Oxford.

Laver, M. J., Shepsle, K. A., 1996. Making and breaking governments: cabinets and legislatures in parliamentary democracies. Cambridge: Cambridge University Press.

Laver, M. J., Shepsle, K. A., 1990. Coalitions and cabinet government. American Political Science Review 84, 873-90.

Lavigne, R., 2010. The political and institutional determinants of fiscal adjustment: Entering and exiting fiscal distress. European Journal of Political Economy, In Press, Corrected Proof, Available online 25 April 2010.

Lijphart, A., 1984. Measures of cabinet durability: a conceptual and empirical evaluation. Comparative Political Studies 17, 265-79.

Locke, C. G., Ahmadi-Esfahani, F. Z., 1998. The origins of the international debt crisis. Comparative Studies in Society and History 40, 223-246.

Milesi-Ferretti, G.M., Perotti, R., Rostagno, M., 2002. Electoral systems and public spending. The Quarterly Journal of Economics 117, 609-657.

Nickell, S., 1981. Biases in dynamic models with fixed effects. Econometrica 49, 141726.

Peltzman, S., 1992. Voters as fiscal conservatives. Quarterly Journal of Economics 107, 327-261.

Perotti, R. Kontopoulos, Y., 2002. Fragmented fiscal policy. Journal of Public Economics 86, 191-222.

Persson, T., Tabellini, G., 2003. The economic effects of constitutions. MIT Press, Cambridge.

Persson, T., Tabellini, G., 2004. Constitutional rules and fiscal policy outcomes. American Economic Review 94, 25-45.

Persson, T., Svenson, L.E.O., 1989. Why a stubborn Conservative would run a deficit: policy with time-inconsistent preferences. The Quarterly Journal of Economics 104, 325-345.

Pettersson-Lidbom, P., 2001. An Empirical Investigation of the Strategic Use of Debt. Journal of Political Economy 109, 570-583.

Przeworski, A., Messeguer, C., 2002. Globalization and Democracy. Instituto Juan March Working Papers 183.

Romero-Ávila, D., Strauch, R., 2008. Public finances and long-term growth in Europe: 
evidence from a panel data analysis. European Journal of Political Economy 24, 172-191.

Roubini, N., 1991. Economic and political determinants of budget deficits in developing countries. Journal of International Money and Finance 10, 549-572.

Roubini, N., Sachs, J., 1989. Government spending and budget deficits in the industrial countries. Economic Policy 4, 100-132.

Roubini, N., Sachs, J., 1988. Political economic determinants of budget deficits in the industrial economies. NBER Working Paper 2682.

Simmons, B., Dobbin, F., Garrett, G., 2006. Introduction: the international diffusion of liberalism. International Organization 60, 781-810.

Stiglitz, J., 2002. Globalization and its discontents. Norton, New York.

Strøm, K., 1990. Minority government and majority rule. Cambridge University Press, New York.

Strøm, K., 1985. Party goals and government performance in parliamentary democracies. American Political Science Review 79, 738-754.

Taylor, M., Herman, V., 1971. Party systems and government stability. American Political Science Review 65, 28-37.

Vergne, C., 2009. Democracy, elections and allocation of public expenditures in developing countries. European Journal of Political Economy 25, 63-77.

Volkerink, B., de Haan, J., 2001. Fragmented government effects on fiscal policy. Public Choice 109, 221-242.

Warwick, P. V., 1979. The durability of coalition governments in parliamentary democracies. Comparative Political Studies 11, 465-498. 


\section{Tables and figures}

Table 1 - Regression analyses

\begin{tabular}{|c|c|c|c|c|c|c|c|c|c|}
\hline & \multicolumn{3}{|c|}{ Model 1: Basic Model } & \multicolumn{3}{|c|}{ Model 2: Full Model with Interactions } & \multicolumn{3}{|c|}{ Model 3: Reduced Model } \\
\hline & $\mathrm{HI}$ & PPI & LOPS & $\mathrm{HI}$ & PPI & LOPS & $\mathrm{HI}$ & PPI & LOPS \\
\hline \multirow{2}{*}{ Lagged Dependent Variable } & $0.618^{\star \star \star}$ & $0.618^{\star \star \star}$ & $0.617^{\star \star \star}$ & $0.638^{\star \star \star}$ & $0.636^{\star \star \star}$ & 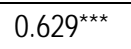 & 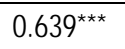 & $0.637^{\star \star \star}$ & $0.631^{\star \star \star}$ \\
\hline & {$[0.051]$} & {$[0.051]$} & {$[0.051]$} & {$[0.053]$} & {$[0.053]$} & {$[0.053]$} & {$[0.054]$} & {$[0.054]$} & {$[0.054]$} \\
\hline \multirow{2}{*}{ GDP Growth } & $-0.136^{\star \star}$ & $-0.137^{\star *}$ & $-0.138^{\star \star}$ & $-0.177^{\star \star \star}$ & $-0.176^{\star \star *}$ & $-0.170^{\star \star \star}$ & $-0.194^{\star \star \star}$ & $-0.194^{\star \star \star}$ & $-0.188^{\star \star \star}$ \\
\hline & {$[0.054]$} & {$[0.054]$} & {$[0.054]$} & {$[0.053]$} & {$[0.053]$} & {$[0.053]$} & {$[0.055]$} & {$[0.055]$} & {$[0.055]$} \\
\hline \multirow{2}{*}{ Interest } & $0.192^{\star \star \star}$ & $0.193^{\star \star \star}$ & $0.192^{\star \star \star}$ & $0.114^{*}$ & $0.121^{*}$ & $0.128^{*}$ & 0.107 & $0.112^{\star}$ & $0.119^{*}$ \\
\hline & {$[0.068]$} & {$[0.068]$} & {$[0.068]$} & {$[0.065]$} & {$[0.066]$} & {$[0.065]$} & {$[0.067]$} & {$[0.067]$} & {$[0.065]$} \\
\hline \multirow{2}{*}{$\begin{array}{l}\text { Openness } \\
\text { (Trade \& Capital Restrictions) }\end{array}$} & 0.096 & 0.095 & 0.089 & 0.073 & 0.068 & 0.056 & & & \\
\hline & {$[0.072]$} & {$[0.072]$} & {$[0.075]$} & {$[0.077]$} & {$[0.077]$} & {$[0.078]$} & & & \\
\hline \multirow{2}{*}{ Unemployment Rate } & $0.189 \star \star \star$ & 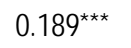 & $0.190^{\star \star \star}$ & $0.158^{\star \star \star}$ & $0.158^{\star \star \star}$ & $0.164^{\star \star \star}$ & $0.140^{\star *}$ & $0.141^{* *}$ & $0.145^{\star \star \star}$ \\
\hline & {$[0.059]$} & {$[0.059]$} & {$[0.058]$} & {$[0.057]$} & {$[0.057]$} & {$[0.057]$} & {$[0.055]$} & {$[0.055]$} & {$[0.056]$} \\
\hline \multirow{2}{*}{$\begin{array}{l}\text { Electoral System } \\
\text { Disproportionality }\end{array}$} & -0.032 & -0.031 & -0.034 & -0.014 & -0.015 & -0.017 & & & \\
\hline & [0.043] & [0.043] & {$[0.043]$} & {$[0.041]$} & {$[0.041]$} & [0.042] & & & \\
\hline \multirow{2}{*}{ Preelectoral Year Share } & -0.413 & -0.409 & -0.404 & -0.219 & -0.233 & -0.199 & & & \\
\hline & {$[0.320]$} & {$[0.320]$} & {$[0.320]$} & [0.309] & {$[0.310]$} & {$[0.315]$} & & & \\
\hline \multirow{2}{*}{$\begin{array}{l}\text { Number of Changes } \\
\text { in Government }\end{array}$} & $0.556^{\star \star \star}$ & $0.555^{\star \star \star}$ & $0.554^{\star \star \star}$ & $0.452^{\star \star \star}$ & $0.457^{\star \star \star}$ & $0.457^{\star \star \star}$ & $0.374^{\star \star \star}$ & $0.374^{\star \star *}$ & $0.389 * \star \star$ \\
\hline & {$[0.151]$} & {$[0.151]$} & {$[0.152]$} & {$[0.146]$} & {$[0.147]$} & {$[0.149]$} & {$[0.122]$} & {$[0.122]$} & {$[0.124]$} \\
\hline \multirow{2}{*}{ Special Interests in Executive } & 1.752 & 1.802 & 1.861 & 1.560 & 1.580 & 1.628 & & & \\
\hline & {$[1.237]$} & [1.251] & {$[1.237]$} & [1.102] & [1.116] & [1.100] & & & \\
\hline \multirow{2}{*}{ Left Executive } & 0.044 & 0.036 & 0.024 & 0.250 & 0.212 & 0.219 & & & \\
\hline & [0.210] & [0.212] & [0.213] & [0.205] & [0.210] & [0.205] & & & \\
\hline \multirow{2}{*}{ Centre Executive } & 0.075 & 0.050 & 0.039 & 0.609 & 0.553 & 0.574 & $1.013^{\star *}$ & $0.996^{* *}$ & $1.016^{\star *}$ \\
\hline & {$[0.451]$} & {$[0.464]$} & {$[0.421]$} & {$[0.443]$} & {$[0.457]$} & [0.418] & {$[0.409]$} & {$[0.411]$} & {$[0.406]$} \\
\hline \multirow{2}{*}{$\begin{array}{l}\text { Form of Fiscal Governance } \\
\text { (Delegation) }\end{array}$} & $-1.898^{\star \star \star}$ & $-1.902^{\star \star \star}$ & $-1.946^{\star \star \star}$ & $-1.944^{\star \star *}$ & -1.930 *** & $-2.026^{\star \star \star}$ & $-1.858^{\star \star *}$ & $-1.853^{\star \star \star}$ & $-1.912^{\star \star \star}$ \\
\hline & {$[0.441]$} & {$[0.441]$} & {$[0.481]$} & {$[0.402]$} & {$[0.404]$} & {$[0.435]$} & {$[0.442]$} & {$[0.441]$} & {$[0.467]$} \\
\hline \multirow{2}{*}{$\begin{array}{l}\text { Form of Fiscal Governance } \\
\text { (Contract) }\end{array}$} & $-0.962^{\star \star \star}$ & $-0.955^{\star \star \star}$ & $-0.948 * \star \star$ & $-0.932^{\star \star \star}$ & $-0.921^{\star \star \star}$ & 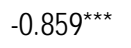 & $-0.939 * \star \star$ & -0.926 *** & $-0.870^{\star \star \star}$ \\
\hline & {$[0.268]$} & {$[0.268]$} & {$[0.264]$} & {$[0.276]$} & {$[0.278]$} & {$[0.270]$} & {$[0.270]$} & {$[0.270]$} & {$[0.266]$} \\
\hline \multirow{2}{*}{ Coalition Majority Cabinet } & 0.515 & 0.506 & 0.501 & $0.846^{\star}$ & $0.790^{\star}$ & $0.823^{*}$ & $0.895^{\star \star}$ & $0.869^{\star \star}$ & $0.913^{\star *}$ \\
\hline & [0.432] & [0.432] & {$[0.426]$} & {$[0.435]$} & [0.433] & [0.432] & {$[0.434]$} & [0.432] & [0.438] \\
\hline \multirow{2}{*}{ Margin to Absolute Majority } & -2.556 & -2.612 & -2.665 & -4.093 & -4.097 & -4.849 & -3.461 & -3.486 & -4.338 \\
\hline & [3.417] & [3.420] & [3.415] & [3.512] & [3.549] & [3.533] & [3.647] & [3.656] & [3.684] \\
\hline \multirow{2}{*}{$\begin{array}{l}\text { Minority Government } \\
\text { (Single Party) }\end{array}$} & 0.082 & 0.077 & 0.073 & 1.607 & 1.410 & $2.279^{\star}$ & 1.598 & 1.464 & $2.453^{*}$ \\
\hline & {$[0.427]$} & {$[0.427]$} & {$[0.426]$} & [1.052] & [1.028] & {$[1.256]$} & [1.055] & {$[1.026]$} & {$[1.277]$} \\
\hline \multirow{2}{*}{$\begin{array}{l}\text { Minority Government } \\
\text { (Coalition) }\end{array}$} & $1.882^{\star \star \star}$ & 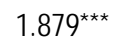 & 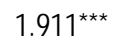 & -0.643 & -0.627 & -1.038 & -0.724 & -0.705 & -1.064 \\
\hline & {$[0.488]$} & {$[0.487]$} & {$[0.493]$} & [1.016] & [1.030] & [1.370] & [0.980] & [0.991] & [1.323] \\
\hline \multirow{2}{*}{ Concentration in Opposition } & -0.154 & -0.252 & -0.457 & -0.553 & -0.549 & -0.720 & -0.159 & -0.155 & -0.300 \\
\hline & [0.921] & [0.933] & [0.993] & [0.872] & {$[0.871]$} & {$[0.950]$} & [0.823] & {$[0.808]$} & {$[0.877]$} \\
\hline \multirow{2}{*}{$\begin{array}{l}\text { Minority Gov. (Single Party) * } \\
\text { Concentration in Opposition }\end{array}$} & & & & $-3.255^{\star}$ & $-2.802^{*}$ & $-3.583^{\star \star}$ & $-3.377^{\star}$ & $-3.040^{\star}$ & $-3.985^{\star *}$ \\
\hline & & & & {$[1.773]$} & {$[1.677]$} & [1.718] & {$[1.794]$} & {$[1.691]$} & {$[1.761]$} \\
\hline Minority Gov. (Coalition) * & & & & 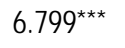 & $6.691^{* \star *}$ & $5.876^{\star \star \star}$ & $6.853^{\star \star \star}$ & $6.836^{\star \star \star}$ & $5.878^{\star \star \star}$ \\
\hline Concentration in Opposition & & & & [1.953] & {$[2.012]$} & [2.092] & {$[1.977]$} & {$[2.027]$} & {$[2.094]$} \\
\hline Observations & 252 & 252 & 252 & 252 & 252 & 252 & 252 & 252 & 252 \\
\hline Number of Countries & 12 & 12 & 12 & 12 & 12 & 12 & 12 & 12 & 12 \\
\hline R-squared & 0.828 & 0.828 & 0.828 & 0.838 & 0.838 & 0.837 & 0.840 & 0.839 & 0.839 \\
\hline
\end{tabular}

Panel-corrected standard errors in brackets. Country and Year dummies not shown.

${ }^{* * *} p<0.01,{ }^{* *} p<0.05,{ }^{*} p<0.1$ 
Table 2 - Regression analyses (Only Minority Governments)

\begin{tabular}{|c|c|c|c|c|c|c|}
\hline & \multicolumn{3}{|c|}{ Model1 } & \multicolumn{3}{|c|}{ Model 2} \\
\hline & $\mathrm{HI}$ & PPI & LOPS & $\mathrm{HI}$ & PPI & LOPS \\
\hline \multirow{2}{*}{ Lagged Dependent Variable } & $0.693^{\star \star \star}$ & $0.691^{\star \star \star}$ & $0.684^{\star \star *}$ & $0.727^{\star \star \star}$ & $0.730^{\star \star \star}$ & $0.721^{* \star *}$ \\
\hline & {$[0.104]$} & {$[0.103]$} & {$[0.104]$} & {$[0.101]$} & {$[0.102]$} & {$[0.101]$} \\
\hline \multirow{2}{*}{ GDP Growth } & $-0.452^{\star \star \star}$ & $-0.455^{\star \star \star}$ & $-0.470 * \star \star$ & $-0.555^{\star \star \star}$ & $-0.539 * * \star$ & $-0.540^{\star \star *}$ \\
\hline & {$[0.172]$} & {$[0.174]$} & {$[0.171]$} & {$[0.170]$} & {$[0.174]$} & {$[0.168]$} \\
\hline \multirow{2}{*}{ Interest } & $0.176^{*}$ & $0.182^{*}$ & $0.201^{\star *}$ & $0.156^{*}$ & $0.161^{*}$ & $0.168^{*}$ \\
\hline & {$[0.097]$} & {$[0.097]$} & {$[0.093]$} & {$[0.093]$} & {$[0.095]$} & {$[0.091]$} \\
\hline \multirow{2}{*}{ Unemployment Rate } & 0.029 & 0.025 & 0.012 & -0.099 & -0.081 & -0.084 \\
\hline & {$[0.158]$} & [0.161] & {$[0.157]$} & [0.162] & [0.165] & [0.158] \\
\hline \multirow{2}{*}{$\begin{array}{l}\text { Number of Changes } \\
\text { in Government }\end{array}$} & 0.119 & 0.126 & 0.141 & 0.085 & 0.086 & 0.097 \\
\hline & {$[0.514]$} & {$[0.514]$} & {$[0.512]$} & [0.493] & {$[0.499]$} & {$[0.494]$} \\
\hline \multirow{2}{*}{ Centre Executive } & -1.445 & -1.497 & -1.627 & -0.454 & -0.732 & -0.501 \\
\hline & [1.510] & [1.517] & {$[1.484]$} & [1.510] & [1.522] & [1.523] \\
\hline \multirow{2}{*}{$\begin{array}{c}\text { Form of Fiscal Governance } \\
\text { (Delegation) }\end{array}$} & -2.652 & -2.221 & -0.587 & 8.610 & 4.508 & 7.670 \\
\hline & [3.331] & [3.248] & [3.419] & {$[5.806]$} & {$[4.604]$} & [5.033] \\
\hline \multirow{2}{*}{$\begin{array}{l}\text { Form of Fiscal Governance } \\
\text { (Contract) }\end{array}$} & $-1.550^{*}$ & -1.485 & -1.200 & -0.504 & -0.659 & -0.416 \\
\hline & {$[0.940]$} & [0.989] & {$[0.950]$} & {$[1.007]$} & {$[1.045]$} & [0.985] \\
\hline \multirow{2}{*}{ Margin to Absolute Majority } & 2.645 & 2.694 & 2.803 & 1.093 & 1.131 & 0.894 \\
\hline & {$[4.407]$} & {$[4.404]$} & {$[4.394]$} & {$[4.278]$} & {$[4.347]$} & [4.329] \\
\hline \multirow{2}{*}{$\begin{array}{l}\text { Minority Government } \\
\text { (Coalition) }\end{array}$} & $2.058^{\star *}$ & $2.184^{\star \star}$ & $2.601 * \star \star$ & -2.052 & -1.153 & -2.349 \\
\hline & {$[0.987]$} & {$[0.900]$} & {$[0.967]$} & {$[2.007]$} & {$[1.879]$} & [2.462] \\
\hline \multirow{2}{*}{ Concentration in Opposition } & 0.840 & 0.219 & -1.814 & $-12.229^{\star}$ & -7.211 & $-10.031^{\star *}$ \\
\hline & [3.621] & [3.387] & [3.258] & {$[6.612]$} & {$[4.954]$} & {$[4.919]$} \\
\hline Minority Gov. (Coalition) * & & & & $13.755^{\star \star}$ & $9.660^{\star *}$ & $10.409^{\star *}$ \\
\hline Concentration in Opposition & & & & [5.922] & {$[4.816]$} & {$[4.793]$} \\
\hline Observations & 69 & 69 & 69 & 69 & 69 & 69 \\
\hline Number of Countries & 9 & 9 & 9 & 9 & 9 & 9 \\
\hline R-squared & 0.836 & 0.835 & 0.836 & 0.852 & 0.848 & 0.851 \\
\hline
\end{tabular}

Standard errors in brackets. Country dummies not shown.

${ }^{* * *} p<0.01,{ }^{* *} p<0.05,{ }^{*} p<0.1$ 
Figure 1: Deficit outcomes of single party minority governments

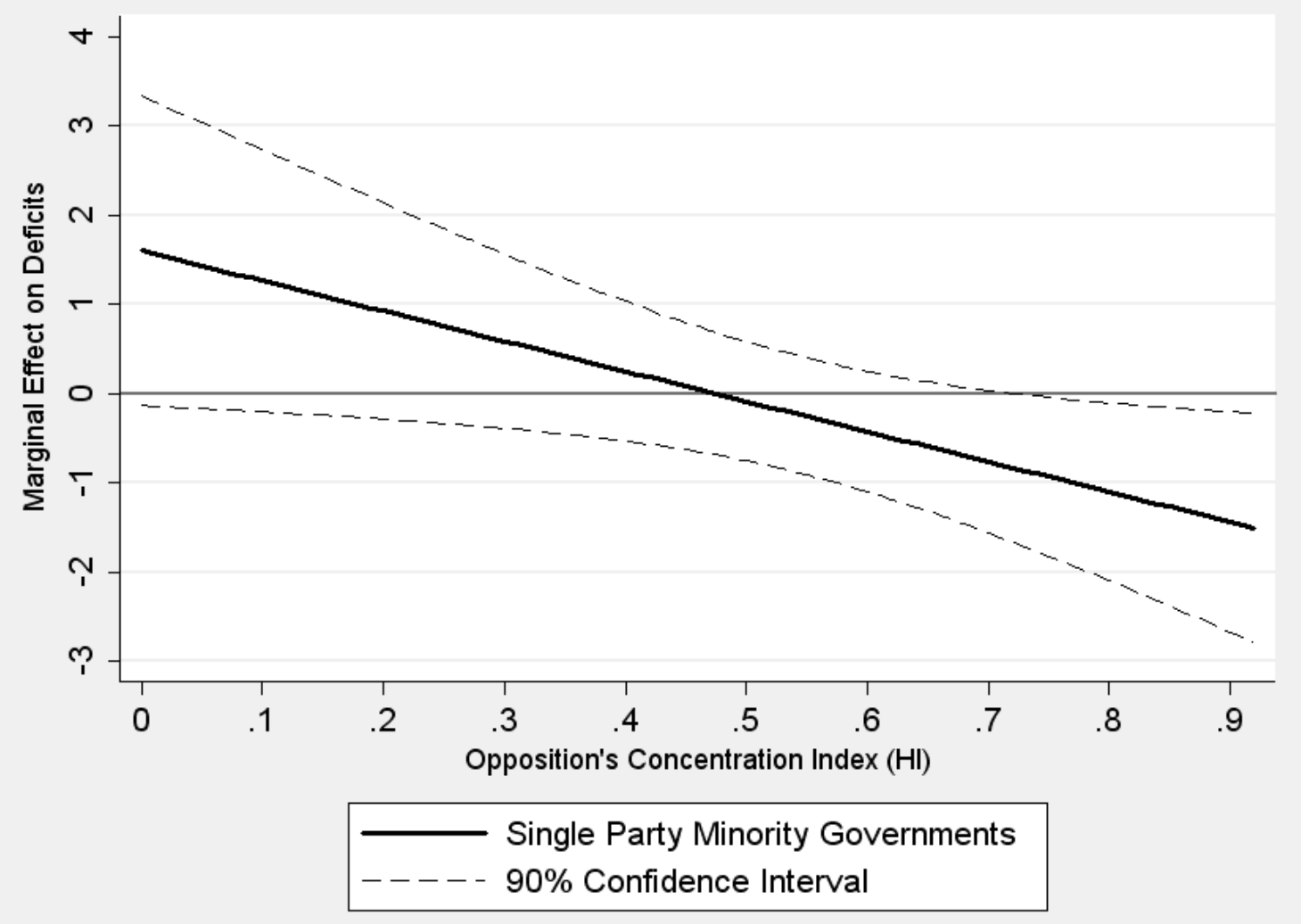


Figure 2: Deficit outcomes of coalition minority governments

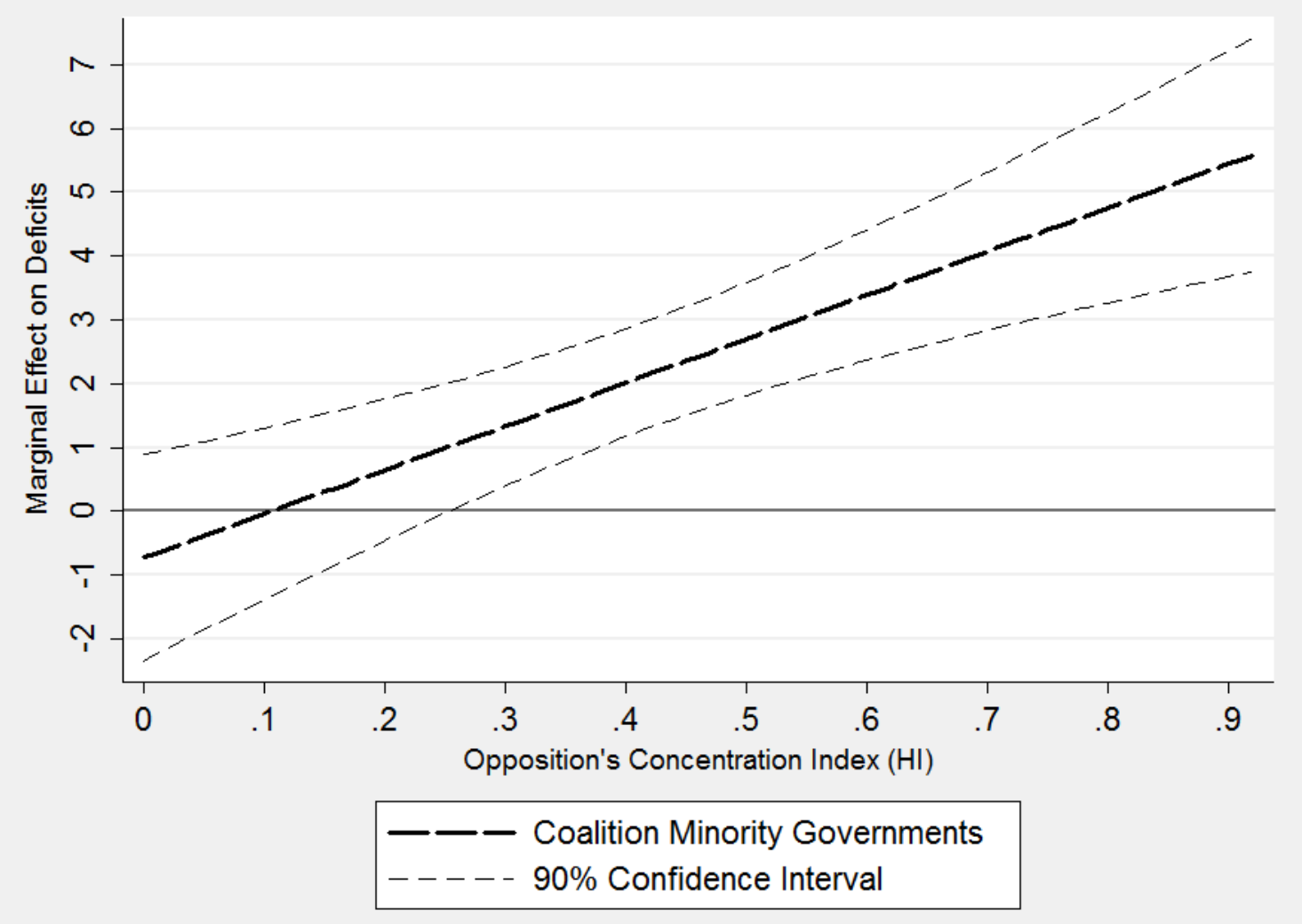


Figure 3: Added variable plot of the minority government and opposition concentration interaction

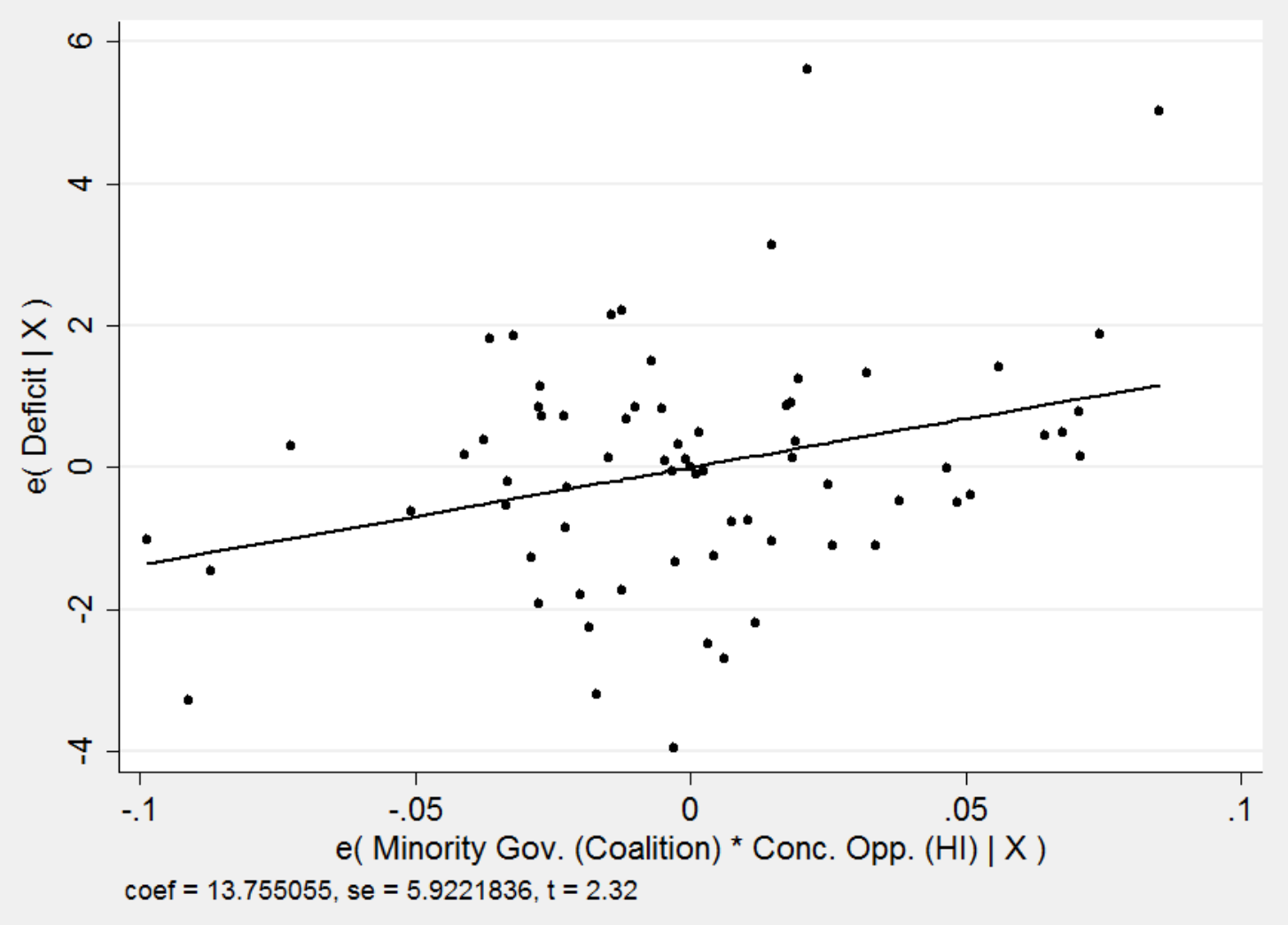

